\title{
Effects of Varying Dietary Protein and Energy Levels on the Production of Lactating Dairy Cows ${ }^{1}$
}

\section{G. A. Broderick}

Agricultural Research Service, USDA

US Dairy Forage Research Center

1925 Linden Drive West, Madison 53706

\section{ABSTRACT}

Forty-five multiparous and 18 primiparous Holstein cows were fed three levels of crude protein (CP), each at three levels of neutral detergent fiber (NDF), to identify optimal dietary CP and energy. Cows were blocked by parity and days in milk into seven groups of nine and randomly assigned to an incomplete $9 \times 9$ Latin square trial with four, 4 -wk periods. Diets were formulated from alfalfa and corn silages, high-moisture corn, soybean meal, minerals, and vitamins. Forage was $60 \%$ alfalfa and $40 \%$ corn silage on all diets; NDF contents of 36,32 , and $28 \%$ were obtained by feeding 75,63 , and $50 \%$ forage, respectively. Dietary CP contents of 15.1, 16.7 , and $18.4 \%$ were obtained by replacing high-moisture corn with soybean meal. Production data were from the last 2 wk of each period. Spot fecal and urine samples were collected from 36 cows to estimate $\mathrm{N}$ excretion using fecal indigestible acid detergent fiber $(\mathrm{ADF})$ and urinary creatinine as markers. There were no interactions $(P \geq 0.08)$ between dietary $\mathrm{CP}$ and NDF for any trait; thus, effects of CP were not confounded by NDF or vice versa. Intake of DM and fat yield were lower on $15.1 \%$ CP than at higher CP. There were linear increases in milk urea and urinary $\mathrm{N}$ excretion and linear decreases in $\mathrm{N}$ efficiency with increasing $\mathrm{CP}$. Increasing CP from 15.1 to $18.4 \%$ reduced milk $\mathrm{N}$ from 31 to $25 \%$ of dietary $\mathrm{N}$, increased urinary $\mathrm{N}$ from 23 to $35 \%$ of dietary $\mathrm{N}$, and reduced fecal $\mathrm{N}$ from 45 to $41 \%$ of dietary $\mathrm{N}$. Decreasing NDF gave linear increases in BW gain, yield of milk, protein, true protein, lactose, and SNF, and milk/DM intake and milk N/N intake, and linear decreases in milk urea. However, fat yield was lower on $28 \%$ than $32 \%$ NDF. Reducing NDF from 36 to $28 \%$ increased purine derivative excretion by $19 \%$, suggesting increased microbial protein. Increasing $\mathrm{CP}$ by

Received: August 15, 2002.

Accepted: October 1, 2002.

E-mail: glenb@dfrc.wisc.edu.

${ }^{1}$ Mention of any trademark or proprietary product in this paper does not constitute a guarantee or warranty of the product by the USDA or the Agricultural Research Service and does not imply its approval to the exclusion of other products that also may be suitable. adding soybean meal to diets fed cows averaging $34 \mathrm{~kg} /$ $\mathrm{d}$ of milk increased intake and fat yield but depressed $\mathrm{N}$ efficiency. Increasing dietary energy by reducing forage improved milk yield and efficiency and decreased excretion of environmentally labile urinary $\mathrm{N}$.

(Key words: protein density, energy density, neutral detergent fiber, nonfiber carbohydrate)

Abbreviation key: HMC = rolled high-moisture shelled corn, $\mathbf{M U N}=$ milk urea $\mathbf{N}, \mathbf{N F C}=$ nonfiber carbohydrate, $\mathbf{S B M}=$ solvent-extracted soybean meal.

\section{INTRODUCTION}

Complex interrelationships exist among dietary protein and energy and the amount of protein that will be utilized by the dairy cow. These interrelationships have important ramifications on overall $\mathrm{N}$ efficiency of the dairy farm (Rotz et al., 1999). Dietary protein supplies metabolizable protein by providing both RDP that is utilized for microbial protein formation and RUP that is digested directly by the cow. High-energy diets stimulate microbial protein synthesis, increasing the supply of this major source of metabolizable protein (Cadorniga et al., 1993). Thus, increasing dietary energy content may increase RDP requirement. It is uneconomical to overfeed protein and energy. Moreover, overfeeding protein results in excessive urinary $\mathrm{N}$, the most environmentally labile form of excreted N (Varel et al., 1999). Overfeeding of concentrates will depress ruminal $\mathrm{pH}$ and may reduce ruminal fiber digestion, milk fat secretion and result in other metabolic problems for the cow (Weimer, 1992; Oliveira et al., 1993; Ekinci and Broderick, 1997).

The main objective of this experiment was to quantify the dietary concentrations of protein and energy under standard feeding conditions that would minimize $\mathrm{N}$ excretion without depressing the yield of milk and milk components. A feeding study was conducted using nine diets-three protein levels at each of three NDF (energy) levels-to produce an array of dietary protein and energy concentrations. Energy levels were altered by varying the dietary concentrations of alfalfa and corn 
Table 1. Composition of diets. ${ }^{1}$

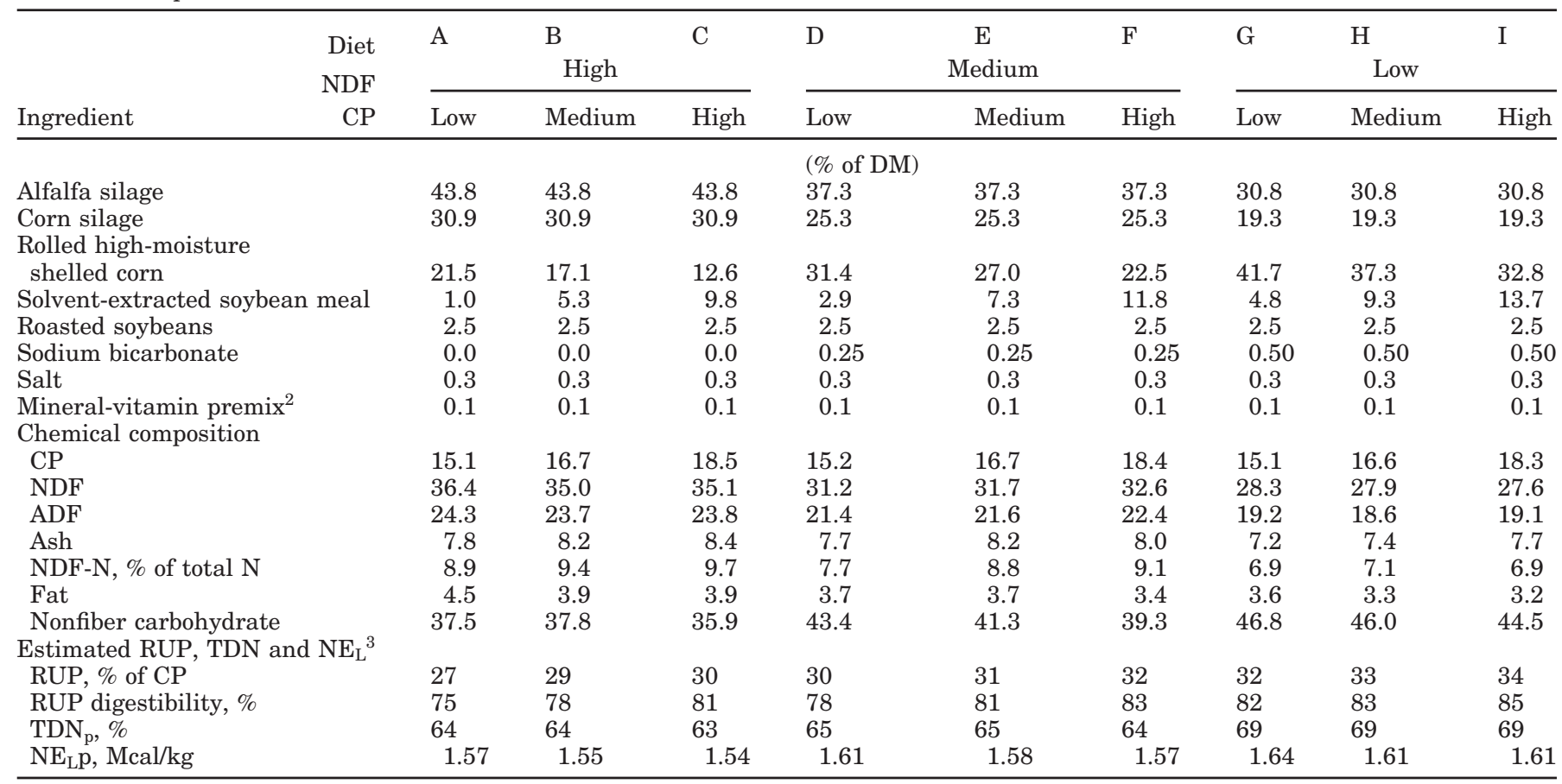

${ }^{1}$ On a DM basis, diets designated as high, medium, and low NDF averaged, respectively, 36, 32, and 28\% NDF; and diets designated as low, medium, and high $\mathrm{CP}$ averaged, respectively, 15.1, 16.7, and 18.4\% CP.

${ }^{2}$ Provided $56 \mathrm{mg}$ of $\mathrm{Zn}, 46 \mathrm{mg}$ of Mn, $22 \mathrm{mg}$ of Fe, $12 \mathrm{mg}$ of Cu, $0.9 \mathrm{mg}$ of I, $0.4 \mathrm{mg}$ of Co, $0.3 \mathrm{mg}$ of Se, $6440 \mathrm{IU}$ of vitamin A, $2000 \mathrm{IU}$ of vitamin $\mathrm{D}$, and $16 \mathrm{IU}$ of vitamin $\mathrm{E} / \mathrm{kg}$ of DM.

${ }^{3}$ Computed from NRC (2001) tables using RUP values for diet ingredients at DMI $=4 \%$ of BW and prorating RUP digestibilities using the proportion of each ingredient in total RUP. TDN $\mathrm{N}_{\mathrm{p}}$ and $\mathrm{NE}_{\mathrm{Lp}}$ were computed using discounts based on the mean DMI observed for each diet plus maintenance requirements computed from overall mean BW $(634 \mathrm{~kg})$.

silage; CP was varied by changing dietary content of soybean meal.

\section{MATERIALS AND METHODS}

Forty-five multiparous Holstein cows, averaging parity 2.9 (SD 1.3), 629 (SD 58) kg BW, 126 (SD 64) DIM, and $44(\mathrm{SD} 8) \mathrm{kg}$ milk/per day, and 18 primiparous Holstein cows averaging 541 (SD 41) kg of BW, 130 (SD 62) DIM, and 34 (SD 11) kg of milk/per day, were blocked into seven groups of nine by parity and DIM. The blocks were allotted randomly to seven different 9 $\times 9$ Latin squares, and cows within blocks were assigned randomly to treatment sequences within each Latin square. The nine diets were fed in the Latin squares as TMR and were formulated from alfalfa and corn silages, high-moisture shelled corn (HMC), solvent-extracted soybean meal (SBM), plus minerals and vitamins, to contain three levels of $\mathrm{CP}$ at each of three levels of NDF (Table 1). Dietary CP was varied by stepwise replacement of 4.4 percentage units of DM from HMC with an equal amount of SBM. Forage was approximately $60 \%$ from alfalfa silage and $40 \%$ from corn silage on all diets; NDF was varied by feeding total forage at 75,63 , and $50 \%$ of DM. The alfalfa silage fed in this trial was from two different silos. That fed during the first 8 wk was harvested at first cutting from May 25 to 28,1999 ; that fed during the second 8 wk was harvested from second cutting from July 1 to 2, 1999. Alfalfa from both harvests was cut using a conventional mower conditioner, field wilted to about $40 \% \mathrm{DM}$, chopped to a theoretical length of $2.9 \mathrm{~cm}$, and ensiled in large bunker silos without additives. Corn silage was harvested at about one-half milk line, chopped to a theoretical length of $1 \mathrm{~cm}$, and ensiled in a large upright silo without additives. Rolling was used when both corn silage (Bal et al., 2000) and HMC were removed from the silo; HMC had a geometric mean particle size of about $2 \mathrm{~mm}$ (Broderick et al., 2001) when fed. Roasted soybeans, with an estimated RUP value of $57 \%$ (Faldet and Satter, 1991), were added at 2.5\% of DM in all TMR. Diets were fed for four, 4 -wk periods (total of 16 wk) in this incomplete Latin square. The first 2 wk of each period was allowed for adaptation to diet; individual means from each cow for production traits from the last 2 wk of each period were analyzed statistically. Cows were milked twice daily and individual milk yields were recorded at each milking. Milk samples 
were collected at two consecutive (p.m. and a.m.) milkings midway through wk 3 and 4 of each period and analyzed for fat, protein, lactose, SNF, and milk urea N (MUN) by infrared methods (AgSource, Verona, WI). Milk samples were deproteinized (Shahani and Sommer, 1951) and analyzed for MUN by an automated colorimetric assay (Broderick and Clayton, 1997), adapted to a flow-injection analyzer and by a urease assay (no. 64-100P; Sigma Chemical Co., St. Louis, MO), as well as for NPN using a combustion method (Mitsubishi TN-05 Nitrogen Analyzer; Mitsubishi Chemical Corp., Tokyo). Milk true protein was computed by subtracting NPN from total protein N (from infrared analysis) using the equation: [(total protein/ $6.38)-\mathrm{NPN}] \times 6.38$. Concentrations and yields of fat, protein, true protein, lactose, and SNF, and MUN concentrations, were computed as the weighted means from p.m. and a.m. milk yields on each test day. Yields of 3.5\% FCM were computed (Sklan et al., 1992). Deproteinized milk from four squares (36 cows) was diluted $50 \%$, vol/vol, with acetonitrile then assayed for allantoin concentration using the HPLC procedure of Shingfield and Offer (1998a). Allantoin also was determined in samples from two squares (18 cows) by the method of Vogels and van der Grift (1970) adapted to a 96-well plate reader. Efficiency of conversion of feed DM was computed for each cow over the last 2 wk of each period by dividing mean milk yield by mean DMI; efficiency of utilization of feed $\mathrm{N}$ similarly was computed for each cow by dividing mean milk $\mathrm{N}$ output (total milk protein/ 6.38) by mean $\mathrm{N}$ intake. Body weights were measured on three consecutive days at the start and end of each period to compute BW change.

All cows were injected with bST (500 mg of Posilac; Monsanto, St. Louis, MO) beginning on $\mathrm{d} 1$ of the trial and at 14-d intervals throughout. Cows were housed in tie stalls and had free access to water during the trial. The TMR were offered once daily at about $1000 \mathrm{~h}$; orts were collected and recorded once daily at about 0900 $\mathrm{h}$. The feeding rate was adjusted daily to yield orts of about $10 \%$ of intake. Weekly composites of each TMR, orts, alfalfa silage, corn silage, and HMC were collected from daily samples of about $0.5 \mathrm{~kg}$ and stored at $-20^{\circ} \mathrm{C}$. Weekly samples of SBM and roasted soybeans were stored at 21 to $24^{\circ} \mathrm{C}$. Proportions of each ration ingredient on an as-fed basis were adjusted weekly based on DM determined by drying weekly composites at $60^{\circ} \mathrm{C}$ (48 h) for alfalfa silage, corn silage, and HMC and at $105^{\circ} \mathrm{C}$ (AOAC, 1980) for SBM and roasted soybeans. Intake of DM was computed based on the $60^{\circ} \mathrm{C} \mathrm{DM}$ values for TMR and orts. After drying, ingredients and TMR were ground through a 1-mm screen (Wiley mill; Arthur H. Thomas, Philadelphia, PA). Samples of alfalfa silage, corn silage, and HMC were analyzed weekly for total $\mathrm{N}$ by combustion assay (Leco 2000; Leco Instruments, Inc., St. Joseph, MI) and for NDF (Hintz et al., 1995). These data, plus representative values for the SBM and roasted soybeans, were used to adjust dietary $\mathrm{CP}$ and NDF on a weekly basis. Period composites of the major diet ingredients and TMR were prepared by mixing equal amounts of DM from the four weekly composites. These samples then were analyzed for DM at $105^{\circ} \mathrm{C}$, ash and OM (AOAC, 1980 ), total $\mathrm{N}$ by combustion assay (Leco Instruments Inc.), and sequentially for $\mathrm{NDF}$ and ADF using heat stable $\alpha$-amylase (Van Soest et al., 1991) and $\mathrm{Na}_{2} \mathrm{SO}_{3}$ (Hintz et al., 1995). The TMR composites also were analyzed for NDF-N using the combustion $\mathrm{N}$ assay (Leco Instruments, Inc.) on residual NDF and for fat (Dairyland Laboratories, Arcadia, WI) to compute of nonfiber carbohydrate (NFC). Data on composition in Table 1 were from analysis of TMR composites. At the end of the trial, weekly composites of alfalfa silage were thawed, water extracts were prepared, deproteinized, and then analyzed for NPN (Muck, 1987) using the combustion $\mathrm{N}$ assay (Mitsubishi Nitrogen Analyzer).

On d 28 of each period, two spot fecal and urine samples were collected from four of the squares (36 cows) at about 6 and $18 \mathrm{~h}$ after feeding. Fecal samples were dried in a forced draft oven $\left(60^{\circ} \mathrm{C} ; 72 \mathrm{~h}\right)$, then ground through a 1-mm screen (Wiley mill). Equal DM from each fecal subsample was mixed to obtain a single composite for each sampled cow during each period. Period fecal and TMR composites were analyzed as described earlier for $\mathrm{DM}$, ash, $\mathrm{OM}, \mathrm{NDF}, \mathrm{ADF}$, and total N, and for indigestible $\mathrm{ADF}$ (the $\mathrm{ADF}$ remaining after 12-d of in situ ruminal incubations; Huhtanen et al., 1994). Indigestible $\mathrm{ADF}$ was used as an internal marker to estimate apparent nutrient digestibility and fecal output (Cochran et al., 1986). Fresh urine samples were acidified by diluting one volume of urine with four volumes of $0.072 \mathrm{~N} \mathrm{H}_{2} \mathrm{SO}_{4}$ and storing at $-20^{\circ} \mathrm{C}$ until analyzed. At the end of the trial, urine samples were thawed at room temperature and filtered through Whatman no. 1 filter paper. Filtrates were analyzed for creatinine using a picric acid assay (Oser, 1965) adapted to a flowinjection analyzer, for total N (Mitsubishi Nitrogen Analyzer), for allantoin using the method of Vogels and van der Grift (1970) adapted to a 96-well plate reader, for uric acid with a commercial kit (no. 683-100P, Sigma) and for urea with the colorimetric method also used for MUN. Daily urine volume and excretion of urea $\mathrm{N}$, total $\mathrm{N}$, and purine derivatives (allantoin plus uric acid) were estimated from urinary creatinine concentration assuming a creatinine excretion rate of 29 $\mathrm{mg} / \mathrm{kg}$ BW (Valadares et al., 1999). 


\section{Statistical Analysis}

The lactation trial was conducted as an incomplete $9 \times 9$ Latin square, replicated 7 times. It was intended from the outset to run the trial for four periods only, rather than for a full nine periods, to avoid confounding effects due to decline in production that would have occurred later in the lactation curve. Seven incomplete $9 \times 9$ Latin squares were constructed by fixing the first column of treatments, ordered A through I, as the diets fed in period 1, then randomly assigning three of eight possible columns of treatments (ordered B, C, . . ,A; $\mathrm{C}, \mathrm{D}, \ldots, \mathrm{B} ; \ldots$. I $, \mathrm{A}, \ldots, \mathrm{H})$ as the subsequent series of diets in periods 2,3 , and 4 . In this arrangement, columns represented periods, and rows represented cows within squares. The seven groups of cows, blocked as described above, were randomly assigned to one of the seven incomplete $9 \times 9$ Latin squares; cows were randomly assigned to one of the nine diet sequences within each square. Production results were analyzed with the mixed procedure of SAS (Littell et al., 1996) using a model, including square, period, cow-withinsquare, dietary CP level $(\mathrm{n}=3)$, dietary level NDF ( $\mathrm{n}$ $=3$ ), the interactions $\mathrm{CP} \times \mathrm{NDF}, \mathrm{CP} \times$ period, and $\mathrm{NDF}$ $\times$ period, plus residual error. All terms were considered fixed, except for cow-within-square and residual error, which were considered random. No significant interactions were found for $\mathrm{CP} \times$ period $(P=0.09$ to 0.99$)$ and $\mathrm{NDF} \times$ period ( $P=0.07$ to 0.98$)$ for any trait; therefore, interpretation of results from this Latin square trial were not confounded. Because the $\mathrm{CP} \times \mathrm{NDF}$ interaction was not significant for any trait $(P=0.08$ to 0.85$)$, differences between least squares means at each level of $\mathrm{CP}$ across all NDF levels and at each level of NDF across all CP levels were reported if the $F$-test for CP or NDF was significant at $\alpha=0.05$. Significance of linear and quadratic contrasts of dietary $\mathrm{CP}$ and NDF levels were determined for each trait in the model. Concentrations of MUN determined by both colorimetric or infrared methods were regressed on MUN assayed by urease enzyme using Proc GLM (SAS, 1989). Estimated urinary excretion of urea $\mathrm{N}$, total $\mathrm{N}$, and allantoin and dietary concentration and intake of $\mathrm{CP}, \mathrm{NFC}$, and NDF, were regressed on MUN (assayed by all three methods) and milk allantoin (assayed by HPLC) using the data from the four squares (36 cows) with Proc GLM (SAS, 1989), using a model that included square, cow-withinsquare, period, and linear and quadratic effects. In one case, the MUN at the maximum response was determined by taking the first derivative of the quadratic equation for which the squared term was significant $(P$ $\leq 0.05)$. The same model was used to regress yield of milk, protein, and true protein on intake of $\mathrm{CP}$ and NFC with data from all 63 cows and to regress esti- mated urinary allantoin excretion and dietary concentration and intake of $\mathrm{CP}, \mathrm{NFC}$, and NDF, and milk allantoin (HPLC assay of Shingfield and Offer, 1998a) on milk allantoin assayed according to Vogels and van der Grift (1970) with data from two squares (18 cows).

\section{RESULTS AND DISCUSSION}

\section{Diet Composition}

Overall, the alfalfa silage fed in this trial averaged $( \pm$ SD) $21.5 \%( \pm 0.9 \%) \mathrm{CP}$ and $41.5 \%( \pm 2.3 \%) \mathrm{NDF}$ on a DM basis, indicating it was typical for high-quality alfalfa (Broderick et al., 1999). Alfalfa fed out from the two different silos was equal in NDF and averaged 22.0 and $21.1 \% \mathrm{CP}$, respectively, during the first and second halves of the trial. The corn silage contained (DM basis) $8.3 \%( \pm 0.7 \%) \mathrm{CP}$ and $38.5 \%( \pm 2.3 \%) \mathrm{NDF}$ and the HMC contained $8.1 \%( \pm 0.3 \%) \mathrm{CP}$ and $8.4 \%( \pm 0.8 \%) \mathrm{NDF}$. The SBM and roasted soybeans fed in the experiment each was from a single batch. The small degree of variation in ingredient composition made it possible to maintain, after correction for DM content, very constant CP and NDF contents in the nine TMR fed over the course of this trial. The alfalfa silage had a mean NPN content of $52 \%$ of total N, which is typical for that forage (Broderick et al., 2001). High concentrations of NPN depress utilization of CP in alfalfa and other hay-crop silages (Nagel and Broderick, 1992) and feeding greater amounts of more fermentable NFC would be expected to improve milk and protein yields (Ekinci and Broderick, 1997; Wilkerson et al., 1997; Kebreab et al., 2000; Valadares et al., 2000).

\section{Milk Production and Nutrient Efficiency}

Surprisingly, the $\mathrm{CP} \times \mathrm{NDF}$ interaction was not significant for any trait $(P=0.08$ to 0.85$)$. Rinne et al. (1999) observed no interactions among yield of energycorrected milk, protein and concentrate supplementation, and forage OM digestibility, when feeding lactating cows diets based on grass silages that ranged from 49 to $65 \%$ NDF (DM basis). Absence of a $\mathrm{CP} \times \mathrm{NDF}$ interaction made it possible to summarize results from the lactation study as least squares means for each trait at each of the three concentrations of dietary CP (averaged over all NDF) and NDF (averaged over all CP). The principal production effects observed with increasing dietary CP were linear increases in DMI, yield of milk, FCM, fat, and protein, and milk protein content (Table 2). Except for DMI, which was greatest at $18.4 \%$ $\mathrm{CP}$, there was no further improvement in yield of milk or milk components beyond $16.7 \%$ CP. Most of the incremental increases in going from 15.1 to $16.7 \%$ dietary CP were modest: $1.1 \mathrm{~kg} / \mathrm{d}$ of milk, $1.5 \mathrm{~kg} / \mathrm{d}$ of FCM, and 
Table 2. Effect of dietary CP content on milk production and composition, nutrient efficiency, and milk $\mathrm{N}$ fractions.

\begin{tabular}{|c|c|c|c|c|c|c|c|}
\hline \multirow[b]{2}{*}{ Trait } & \multicolumn{3}{|c|}{$\mathrm{CP}, \%$ of $\mathrm{DM}$} & \multirow[b]{2}{*}{$\mathrm{SE}$} & \multicolumn{3}{|c|}{$\mathrm{P}>\mathrm{F}^{1}$} \\
\hline & 15.1 & 16.7 & 18.4 & & $\mathrm{CP}$ & Linear & Quadratic \\
\hline \multicolumn{8}{|c|}{ Intake and yield, $\mathrm{kg} / \mathrm{d}$} \\
\hline DMI & $21.2^{\mathrm{c}}$ & $22.1^{\mathrm{b}}$ & $22.6^{\mathrm{a}}$ & 0.3 & $<0.01$ & $<0.01$ & 0.30 \\
\hline $\mathrm{N}$ intake & $0.512^{\mathrm{c}}$ & $0.593^{\mathrm{b}}$ & $0.666^{\mathrm{a}}$ & 0.007 & $<0.01$ & $<0.01$ & 0.49 \\
\hline BW gain & 0.45 & 0.57 & 0.55 & 0.08 & 0.48 & 0.37 & 0.41 \\
\hline Milk & $33.0^{\mathrm{b}}$ & $34.1^{\mathrm{a}}$ & $34.1^{\mathrm{a}}$ & 0.6 & 0.01 & 0.01 & 0.14 \\
\hline $3.5 \% \mathrm{FCM}$ & $33.1^{\mathrm{b}}$ & $34.6^{\mathrm{a}}$ & $34.3^{\mathrm{a}}$ & 0.6 & 0.01 & 0.02 & 0.04 \\
\hline Fat & $1.15^{\mathrm{b}}$ & $1.23^{\mathrm{a}}$ & $1.20^{\mathrm{a}}$ & 0.03 & $<0.01$ & 0.03 & 0.01 \\
\hline Protein & $0.99^{\mathrm{b}}$ & $1.02^{\mathrm{a}}$ & $1.02^{\mathrm{a}}$ & 0.02 & 0.05 & 0.04 & 0.19 \\
\hline True protein & 0.92 & 0.95 & 0.94 & 0.02 & 0.21 & 0.33 & 0.14 \\
\hline Lactose & 1.66 & 1.68 & 1.69 & 0.03 & 0.42 & 0.21 & 0.69 \\
\hline $\mathrm{SNF}$ & 2.97 & 3.03 & 3.04 & 0.06 & 0.20 & 0.11 & 0.42 \\
\hline \multicolumn{8}{|l|}{ Milk composition, \% } \\
\hline Fat & 3.51 & 3.66 & 3.60 & 0.07 & 0.08 & 0.20 & 0.07 \\
\hline Protein & $2.99^{\mathrm{b}}$ & $3.03^{\mathrm{a}}$ & $3.02^{\mathrm{a}}$ & 0.03 & 0.03 & 0.05 & 0.07 \\
\hline True protein & 2.80 & 2.82 & 2.79 & 0.03 & 0.12 & 0.50 & 0.06 \\
\hline Lactose & 4.97 & 4.96 & 4.96 & 0.02 & 0.44 & 0.20 & 0.95 \\
\hline $\mathrm{SNF}$ & 8.93 & 8.98 & 8.96 & 0.04 & 0.11 & 0.31 & 0.06 \\
\hline \multicolumn{8}{|c|}{ Efficiency, yield/intake } \\
\hline Milk/DMI & $1.56^{\mathrm{a}}$ & $1.55^{\mathrm{a}}$ & $1.51^{\mathrm{b}}$ & 0.02 & 0.02 & 0.01 & 0.47 \\
\hline Milk N/N intake & $0.303^{\mathrm{a}}$ & $0.270^{\mathrm{b}}$ & $0.239^{c}$ & 0.004 & $<0.01$ & $<0.01$ & 0.72 \\
\hline \multicolumn{8}{|l|}{ Milk NPN fractions } \\
\hline Urea ${ }^{2}{ }^{2} \mathrm{mg} / \mathrm{dl}$ & $9.2^{\mathrm{c}}$ & $12.4^{\mathrm{b}}$ & $15.9^{\mathrm{a}}$ & 0.2 & $<0.01$ & $<0.01$ & 0.34 \\
\hline Allantoin ${ }^{3} \mathrm{~m} M$ & 0.141 & 0.138 & 0.152 & 0.006 & 0.08 & 0.31 & 0.04 \\
\hline Total NPN, mg/dl & $29.3^{\mathrm{c}}$ & $32.5^{\mathrm{b}}$ & $36.5^{\mathrm{a}}$ & 0.3 & $<0.01$ & $<0.01$ & 0.19 \\
\hline Urea N/NPN, \% & $31.5^{\mathrm{c}}$ & $38.0^{\mathrm{b}}$ & $43.5^{\mathrm{a}}$ & 0.5 & $<0.01$ & $<0.01$ & 0.31 \\
\hline
\end{tabular}

${ }^{\mathrm{a}, \mathrm{b}, \mathrm{c}}$ Least squares means within the same row without a common superscript differ $(P<0.05)$.

${ }^{1}$ Probability of a significant effect of $\mathrm{CP}$ or of a linear or quadratic effect of $\mathrm{CP}$ concentration in the diet. ${ }^{2}$ Milk urea $\mathrm{N}$ determined using a colorimetric assay (Broderick and Clayton, 1997).

${ }^{3}$ Milk allantoin determined using an HPLC method (Shingfield and Offer, 1998a) on samples from four squares (36 cows).

$0.03 \mathrm{~kg} / \mathrm{d}$ of protein. Only the increase in fat yield was more substantial $-0.08 \mathrm{~kg} / \mathrm{d}$ at $16.7 \% \mathrm{CP}$ and $0.05 \mathrm{~kg} /$ $\mathrm{d}$ at $18.4 \% \mathrm{CP}$ vs. that at $15.1 \% \mathrm{CP}$. Greater fat yield at $16.7 \% \mathrm{CP}$ gave rise to a significant quadratic effect of dietary CP; maximal fat yield was predicted at $17.1 \%$ dietary CP. It is interesting that true protein yield (estimated by correcting total protein assayed by infrared analysis for milk NPN content) was not significantly altered by dietary CP content. Several factors related to nutrient efficiency became less favorable when dietary CP was increased (Table 2). Similar feed efficiency at 15.1 and $16.7 \% \mathrm{CP}$ suggested that the small response in milk yield at $16.7 \% \mathrm{CP}$ was due at least partly to the small increase in DMI. The further increase in DMI at $18.4 \% \mathrm{CP}$ was not accompanied by more milk and milk yield/DMI declined. When dietary CP increased, there was a highly significant linear decrease in $\mathrm{N}$ efficiency.

Except for fat yield, increasing dietary energy density and NFC by reducing forage and NDF increased weight gain and yield of milk and all milk components; these responses were linear (Table 3). Moreover, milk concentrations of protein, true protein, lactose, and SNF also were increased linearly with greater dietary energy.
Over this same range of NFC, there were linear and quadratic declines in milk fat content. Fat yield was lower at $28 \% \mathrm{NDF}$ than at the intermediate energy density (32\% NDF); thus, there also was a quadratic effect of dietary NDF on fat yield. Significant linear increases in both DM and $\mathrm{N}$ efficiency were observed with increasing dietary energy content. Feed intake was not altered by increasing dietary energy density.

Under the conditions of this trial, production of milk and milk components clearly was maximal at $16.7 \% \mathrm{CP}$, and there was strong evidence of depressed nutrient efficiency, especially for N, at $18.4 \%$ CP. Dietary CP was increased by replacing HMC with a protein source with an estimated RUP of $35 \%$ at DMI $=4 \%$ of BW (NRC, 2001). Factors influencing utilization of dietary $\mathrm{CP}$ are complex and related to supplying sufficient RDP to meet the needs of ruminal microbes plus sufficient RUP of adequate intestinal digestibility, with an AA pattern complementary to microbial protein, such that the absorbed AA requirements of the cow are met. Information on RDP and RUP values for specific ration ingredients often is unreliable. Increasing the fermentable energy content of the diet by reducing NDF and increasing NFC likely stimulated greater microbial protein 
Table 3. Effect of dietary NDF content on milk production and composition, nutrient efficiency, and milk $\mathrm{N}$ fractions.

\begin{tabular}{|c|c|c|c|c|c|c|c|}
\hline \multirow[b]{2}{*}{ Trait } & \multicolumn{3}{|c|}{$\mathrm{NDF}, \%$ of DM } & \multirow[b]{2}{*}{$\mathrm{SE}$} & \multicolumn{3}{|c|}{$P>\mathrm{F}^{1}$} \\
\hline & 36 & 32 & 28 & & $\mathrm{NDF}$ & Linear & Quadratic \\
\hline \multicolumn{8}{|l|}{ Intake and yield, $\mathrm{kg} / \mathrm{d}$} \\
\hline DMI & 21.7 & 22.2 & 22.0 & 0.3 & 0.16 & 0.36 & 0.10 \\
\hline $\mathrm{N}$ intake & 0.589 & 0.597 & 0.584 & 0.007 & 0.16 & 0.42 & 0.08 \\
\hline BW gain & $0.39^{\mathrm{b}}$ & $0.47^{\mathrm{b}}$ & $0.71^{\mathrm{a}}$ & 0.08 & 0.01 & $<0.01$ & 0.38 \\
\hline Milk & $31.2^{\mathrm{c}}$ & $33.9^{b}$ & $36.2^{\mathrm{a}}$ & 0.6 & $<0.01$ & $<0.01$ & 0.64 \\
\hline $3.5 \% \mathrm{FCM}$ & $32.9^{\mathrm{b}}$ & $34.7^{\mathrm{a}}$ & $34.3^{\mathrm{a}}$ & 0.6 & $<0.01$ & 0.01 & 0.02 \\
\hline Fat & $1.19^{\mathrm{ab}}$ & $1.24^{\mathrm{a}}$ & $1.15^{\mathrm{b}}$ & 0.03 & $<0.01$ & 0.11 & 0.01 \\
\hline Protein & $0.91^{\mathrm{c}}$ & $1.01^{\mathrm{b}}$ & $1.10^{\mathrm{a}}$ & 0.02 & $<0.01$ & $<0.01$ & 0.77 \\
\hline True protein & $0.85^{\mathrm{c}}$ & $0.94^{\mathrm{b}}$ & $1.02^{\mathrm{a}}$ & 0.02 & $<0.01$ & $<0.01$ & 0.78 \\
\hline Lactose & $1.54^{\mathrm{c}}$ & $1.68^{\mathrm{b}}$ & $1.81^{\mathrm{a}}$ & 0.03 & $<0.01$ & $<0.01$ & 0.72 \\
\hline SNF & $2.76^{\mathrm{c}}$ & $3.02^{\mathrm{b}}$ & $3.26^{\mathrm{a}}$ & 0.06 & $<0.01$ & $<0.01$ & 0.72 \\
\hline \multicolumn{8}{|l|}{ Milk composition, \% } \\
\hline Fat & $3.86^{\mathrm{a}}$ & $3.70^{\mathrm{b}}$ & $3.22^{\mathrm{c}}$ & 0.07 & $<0.01$ & $<0.01$ & 0.01 \\
\hline Protein & $2.95^{\mathrm{c}}$ & $3.01^{b}$ & $3.08^{\mathrm{a}}$ & 0.03 & $<0.01$ & $<0.01$ & 0.92 \\
\hline True protein & $2.74^{\mathrm{c}}$ & $2.80^{\mathrm{b}}$ & $2.87^{\mathrm{a}}$ & 0.03 & $<0.01$ & $<0.01$ & 0.78 \\
\hline Lactose & $4.92^{\mathrm{b}}$ & $4.97^{\mathrm{a}}$ & $4.99^{\mathrm{a}}$ & 0.02 & $<0.01$ & $<0.01$ & 0.20 \\
\hline SNF & $8.85^{\mathrm{c}}$ & $8.96^{\mathrm{b}}$ & $9.06^{\mathrm{a}}$ & 0.04 & $<0.01$ & $<0.01$ & 0.61 \\
\hline \multicolumn{8}{|c|}{ Efficiency, yield/intake } \\
\hline Milk/DMI & $1.44^{\mathrm{c}}$ & $1.53^{\mathrm{b}}$ & $1.65^{\mathrm{a}}$ & 0.02 & $<0.01$ & $<0.01$ & 0.48 \\
\hline Milk N/N intake & $0.249^{\mathrm{c}}$ & $0.269^{\mathrm{b}}$ & $0.295^{\mathrm{a}}$ & 0.004 & $<0.01$ & $<0.01$ & 0.46 \\
\hline \multicolumn{8}{|l|}{ Milk NPN fractions } \\
\hline Urea $\mathrm{N},{ }^{2} \mathrm{mg} / \mathrm{dl}$ & $13.3^{\mathrm{a}}$ & $12.7^{\mathrm{b}}$ & $11.5^{\mathrm{c}}$ & 0.2 & $<0.01$ & $<0.01$ & 0.20 \\
\hline Allantoin, ${ }^{3} \mathrm{~m} M$ & $0.139^{b}$ & $0.147^{\mathrm{a}}$ & $0.143^{\mathrm{a}}$ & 0.006 & 0.03 & 0.03 & 0.09 \\
\hline Total NPN, mg/dl & 32.9 & 33.0 & 32.4 & 0.3 & 0.10 & 0.12 & 0.14 \\
\hline Urea N/NPN, \% & $40.0^{\mathrm{a}}$ & $37.9^{\mathrm{b}}$ & $35.1^{\mathrm{c}}$ & 0.5 & $<0.01$ & $<0.01$ & 0.48 \\
\hline
\end{tabular}

${ }^{\mathrm{a}, \mathrm{b}, \mathrm{c}}$ Least squares means within the same row without a common superscript $\operatorname{differ}(P<0.05)$.

${ }^{1}$ Probability of a significant effect of NDF or of a linear or quadratic effect of NDF concentration in the diet.

${ }^{2}$ Milk urea N determined using a colorimetric assay (Broderick and Clayton, 1997).

${ }^{3}$ Milk allantoin determined using an HPLC method (Shingfield and Offer, 1998a) on samples from four square (36 cows).

synthesis in the rumen. However, reducing dietary NDF required reducing alfalfa silage as well as corn silage; alfalfa CP was replaced with that from SBM. Thus, elevated metabolizable protein supply at lower NDF would have derived from both increased SBM RUP and microbial protein formation. Metabolizable protein supply was computed with tabulated RUP data for the diets fed in these trials (Table 1) and by estimating microbial protein at $130 \mathrm{~g} / \mathrm{kg}$ of discounted TDN (NRC, 2001). These computations suggested that most of the increased metabolizable protein with increased dietary $\mathrm{CP}$ and NFC would have derived from RUP. Computed metabolizable protein supplies were 1890, 2170, and $2380 \mathrm{~g} / \mathrm{d}$ on $15.1,16.7$, and $18.4 \%$ CP diets with $82 \%$ of the increase on the two higher $\mathrm{CP}$ diets estimated to be from SBM RUP and 18\% from greater microbial protein synthesis due to greater DMI. Computed metabolizable protein supplies were 1990, 2180, and 2270 $\mathrm{g} / \mathrm{d}$ on 36,32 , and $28 \%$ NDF. Extra metabolizable protein from greater RUP on the lower NDF diets was, respectively, 119 and $214 \mathrm{~g} / \mathrm{d}$ and that deriving from greater microbial protein was, respectively, 67 and 63 $\mathrm{g} / \mathrm{d}$.

\section{Digestibility and Excretion}

There was no change in apparent digestibility of DM and $\mathrm{OM}$ with increasing dietary $\mathrm{CP}$; however, NDF and ADF digestibility both increased linearly with dietary $\mathrm{CP}$ (Table 4). Digestion of NDF in poor-quality forages fed to beef cows was elevated with SBM supplementation (Mathis et al., 1999). Greater intake of RDP may stimulate fiber digestion by increasing the supply of branched-chain VFA. Supplementing low-protein diets with branched-chain VFA increased OM and fiber digestion in the rumen of cattle (Misra and Thakur, 2001). No ruminal sampling was conducted in the present study; however, we have observed elevated ruminal concentrations of branched-chain VFA with feeding increased dietary CP from alfalfa silage (Hristov and Broderick, 1996) and SBM (Broderick, 1986). The linear increase in apparent $\mathrm{N}$ digestibility with elevated dietary $\mathrm{CP}$ was the usual result of dilution of metabolic fecal $\mathrm{N}$ as well as the effect of greater intake of SBM, a highly digestible protein source.

Linear effects of greater fecal DM $(P=0.03)$ and $\mathrm{N}$ excretion $(P<0.01)$ were observed with increased di- 
Table 4. Effect of dietary CP content on nutrient digestibility and nitrogen metabolism (LS means from spot sampling of 36 cows).

\begin{tabular}{|c|c|c|c|c|c|c|c|}
\hline \multirow[b]{2}{*}{ Trait } & \multicolumn{3}{|c|}{$\mathrm{CP}, \%$ of $\mathrm{DM}$} & \multirow[b]{2}{*}{$\mathrm{SE}$} & \multicolumn{3}{|c|}{$P>\mathrm{F}^{1}$} \\
\hline & 15.1 & 16.7 & 18.4 & & $\mathrm{CP}$ & Linear & Quadratic \\
\hline \multicolumn{8}{|l|}{ Apparent digestibility, \% } \\
\hline $\mathrm{DM}$ & 62.7 & 62.8 & 63.1 & 0.5 & 0.76 & 0.50 & 0.77 \\
\hline $\mathrm{OM}$ & 63.7 & 63.7 & 64.2 & 0.5 & 0.64 & 0.39 & 0.69 \\
\hline $\mathrm{NDF}$ & $37.0^{\mathrm{b}}$ & $37.4^{\mathrm{b}}$ & $39.8^{\mathrm{a}}$ & 0.8 & 0.03 & 0.01 & 0.28 \\
\hline $\mathrm{ADF}$ & $37.2^{\mathrm{b}}$ & $37.0^{\mathrm{b}}$ & $39.9^{\mathrm{a}}$ & 0.9 & 0.03 & 0.02 & 0.13 \\
\hline $\mathrm{N}$ & $54.5^{\mathrm{b}}$ & $55.9^{\mathrm{b}}$ & $58.9^{\mathrm{a}}$ & 0.9 & $<0.01$ & $<0.01$ & 0.35 \\
\hline \multicolumn{8}{|l|}{ Excretion } \\
\hline Fecal DM, kg/d & 7.95 & 8.25 & 8.33 & 0.21 & 0.08 & 0.03 & 0.47 \\
\hline Fecal N, g/d & $236^{\mathrm{b}}$ & $264^{\mathrm{a}}$ & $273^{\mathrm{a}}$ & 8 & $<0.01$ & $<0.01$ & 0.12 \\
\hline Urine volume, $\mathrm{L} / \mathrm{d}$ & $20.8^{\mathrm{c}}$ & $24.4^{\mathrm{b}}$ & $27.3^{\mathrm{a}}$ & 1.2 & $<0.01$ & $<0.01$ & 0.71 \\
\hline Urinary urea-N, g/d & $119^{c}$ & $172^{\mathrm{b}}$ & $216^{\mathrm{a}}$ & 4 & $<0.01$ & $<0.01$ & 0.25 \\
\hline Urinary $\mathrm{N}, \mathrm{g} / \mathrm{d}$ & $140^{\mathrm{c}}$ & $193^{\mathrm{b}}$ & $236^{\mathrm{a}}$ & 5 & $<0.01$ & $<0.01$ & 0.20 \\
\hline Fecal N, \% of intake & $45.5^{\mathrm{a}}$ & $44.1^{\mathrm{a}}$ & $41.1^{b}$ & 0.9 & $<0.01$ & $<0.01$ & 0.35 \\
\hline Urinary $\mathrm{N}, \%$ of intake & $27.4^{\mathrm{c}}$ & $33.0^{\mathrm{b}}$ & $35.7^{\mathrm{a}}$ & 0.7 & $<0.01$ & $<0.01$ & 0.04 \\
\hline Urinary $\mathrm{PD},{ }^{2} \mathrm{mmol} / \mathrm{d}$ & $377^{\mathrm{b}}$ & $404^{\mathrm{a}}$ & $400^{\mathrm{ab}}$ & 11 & 0.05 & 0.06 & 0.12 \\
\hline
\end{tabular}

a,b,c The three means within the same row without a common superscript are different $(P<0.05)$.

${ }^{1}$ Probability of a significant effect of $\mathrm{CP}$ or of a linear or quadratic effect of $\mathrm{CP}$ concentration in the diet. ${ }^{2} \mathrm{PD}=$ total purine derivatives (allantoin plus uric acid).

etary CP (Table 4). These likely were related to the linear increase in DMI described earlier (Table 2) as well as to excretion of undigested dietary CP. Urinary purine derivative excretion, which derives mainly from catabolism of absorbed purines of ruminal microbial origin (Stangassinger et al., 1995), also was elevated at $16.7 \% \mathrm{CP}$ vs. $15.1 \% \mathrm{CP}$, with purine derivative excretion at $18.4 \%$ being intermediate. Greater DMI at the two higher CP diets would have provided more fermentable substrate to the rumen, stimulating greater microbial growth. That an increase of $27 \mathrm{mmol} / \mathrm{d}(7 \%)$ in purine derivative excretion was detected as significant suggested that spot sampling procedures, along with urine output estimated from creatinine concentration, would prove a sensitive method for use in routine lactation studies. Shingfield and Offer (1998b) found spot urine sampling significantly less reliable than total urine collection for estimating excretion of total purine derivatives in lactating cows. The linear increase in urine volume and urinary excretion of urea $\mathrm{N}$ and total $\mathrm{N}$ with increased dietary $\mathrm{CP}$ were expected to parallel the increased absorption of ruminal degradation products and metabolizable protein that would accompany increased SBM intake. The greater quantities of $\mathrm{N}$ metabolites requiring excretion likely increased the volume of urinary water required to dilute these compounds (Valadares et al., 1999). Elevation of urinary $\mathrm{N}$ output was substantial: urea $\mathrm{N}$ and total $\mathrm{N}$ went up 82 and $69 \%$ when dietary CP increased from 15.1 to $18.4 \%$. Urea $\mathrm{N}$ accounted for essentially all of this increase in total $\mathrm{N}$ excretion. Over the range of $\mathrm{CP}$ intakes in this trial, fecal $\mathrm{N}$ declined from about 46 to $41 \%$ of consumed $\mathrm{N}$, while the proportion of consumed $\mathrm{N}$ appearing in the urine increased from about 27 to nearly $36 \%$. Thus, the net effect of increasing $\mathrm{CP}$ intake by increasing dietary SBM was to cause a small (3\%) increase milk $\mathrm{N}$ secretion but mainly to divert $\mathrm{N}$ excretion from the feces to urinary urea. This form of excretory $\mathrm{N}$ is the most labile. Following contact with microbial ureases in the environment (e.g., in feces; Muck, 1982), urea will be rapidly hydrolyzed to ammonia and lost by volatilization (James et al., 1999).

As expected, there were linear increases in apparent $\mathrm{DM}$ and $\mathrm{OM}$ digestibility, and linear declines in apparent NDF and ADF digestibility and fecal DM output, with decreasing dietary NDF content (Table 5). The estimated increase in DM digestibility (2.4 percentage units) over this range of dietary NDF was less than half of the increase (5.3 percentage units; Table 1) in discounted TDN (TDNp) computed for these diets based on NRC (2001) assumptions. Increased dietary NFC is often observed to depress fiber digestion, partly by depressing ruminal pH (Weimer, 1992; Oliveira et al., 1993). However, ruminal $\mathrm{pH}$ was not measured in this trial. Apparent $\mathrm{N}$ digestibility was not altered by source of dietary carbohydrate, suggesting that total tract digestibility of CP was similar for alfalfa silage, which was reduced, and SBM, which was increased, when diets were formulated to contain reduced NDF. Fecal $\mathrm{N}$ output and urinary volume also were not affected by source of dietary carbohydrate. However, there were linear decreases in urinary excretion of urea $\mathrm{N}$ and total $\mathrm{N}$ with reduced NDF: the proportion of dietary $\mathrm{N}$ excreted in the urine fell by 4.0 percentage units over the range of NDF and NFC fed in this study. The decline was consistent with the improvement in $\mathrm{N}$ efficiency 
Table 5. Effect of dietary NDF content on nutrient digestibility and nitrogen metabolism (LS means from spot sampling of 36 cows).

\begin{tabular}{|c|c|c|c|c|c|c|c|}
\hline \multirow[b]{2}{*}{ Trait } & \multicolumn{3}{|c|}{$\mathrm{NDF}, \%$ of DM } & \multirow[b]{2}{*}{$\mathrm{SE}$} & \multicolumn{3}{|c|}{$P>\mathrm{F}^{1}$} \\
\hline & 36 & 32 & 28 & & $\mathrm{NDF}$ & Linear & Quadratic \\
\hline \multicolumn{8}{|l|}{ Apparent digestibility, \% } \\
\hline DM & $61.8^{\mathrm{b}}$ & $62.6^{\mathrm{b}}$ & $64.2^{\mathrm{a}}$ & 0.5 & $<0.01$ & $<0.01$ & 0.54 \\
\hline $\mathrm{OM}$ & $63.0^{\mathrm{b}}$ & $63.5^{\mathrm{b}}$ & $65.2^{\mathrm{a}}$ & 0.5 & $<0.01$ & $<0.01$ & 0.29 \\
\hline $\mathrm{NDF}$ & $40.0^{\mathrm{a}}$ & $38.0^{\mathrm{ab}}$ & $36.2^{\mathrm{b}}$ & 0.8 & $<0.01$ & $<0.01$ & 0.92 \\
\hline $\mathrm{ADF}$ & $39.6^{\mathrm{a}}$ & $37.9^{\mathrm{ab}}$ & $36.5^{\mathrm{b}}$ & 0.9 & 0.03 & 0.01 & 0.90 \\
\hline $\mathrm{N}$ & 55.9 & 56.7 & 56.7 & 0.9 & 0.72 & 0.49 & 0.67 \\
\hline \multicolumn{8}{|l|}{ Excretion } \\
\hline Fecal DM, kg/d & $8.37^{\mathrm{a}}$ & $8.28^{\mathrm{a}}$ & $7.88^{\mathrm{b}}$ & 0.21 & 0.02 & 0.01 & 0.35 \\
\hline Fecal N, g/d & 260 & 258 & 255 & 8 & 0.80 & 0.51 & 0.99 \\
\hline Urine volume, L/d & 24.2 & 24.0 & 24.3 & 1.2 & 0.97 & 0.93 & 0.80 \\
\hline Urinary urea-N, $\mathrm{g} / \mathrm{d}$ & $181^{\mathrm{a}}$ & $168^{\mathrm{b}}$ & $157^{\mathrm{c}}$ & 4 & $<0.01$ & $<0.01$ & 0.78 \\
\hline Urinary $\mathrm{N}, \mathrm{g} / \mathrm{d}$ & $200^{\mathrm{a}}$ & $189^{\mathrm{b}}$ & $180^{\mathrm{b}}$ & 5 & $<0.01$ & $<0.01$ & 0.83 \\
\hline Fecal N, \% of intake & 44.1 & 43.3 & 43.3 & 0.9 & 0.71 & 0.48 & 0.67 \\
\hline Urinary $N, \%$ of intake & $34.3^{\mathrm{a}}$ & $31.6^{\mathrm{b}}$ & $30.3^{\mathrm{b}}$ & 0.7 & $<0.01$ & $<0.01$ & 0.34 \\
\hline Urinary $\mathrm{PD},{ }^{2} \mathrm{mmol} / \mathrm{d}$ & $356^{\mathrm{c}}$ & $399^{\mathrm{b}}$ & $425^{\mathrm{a}}$ & 11 & $<0.01$ & $<0.01$ & 0.43 \\
\hline
\end{tabular}

a,b,c The three means within the same row without a common superscript are different $(P<0.05)$.

${ }^{1}$ Probability of a significant effect of NDF or of a linear or quadratic effect of NDF concentration in the diet.

${ }^{2} \mathrm{PD}=$ total purine derivatives (allantoin plus uric acid).

observed in this trial with increasing dietary energy (Table 3) and reported in earlier studies (Ekinci and Broderick, 1997; Vagnoni and Broderick, 1997; Valadares et al., 2000).

The linear increase in purine derivative excretion in the urine probably was related to increased microbial protein formation from greater ruminal fermentation (Table 5). Using the regression equation of Vagnoni et al. (1997) to estimate abomasal purine flow from urinary purine derivative excretion and a mean ratio of $3.99 \mathrm{~g}$ of microbial $\mathrm{CP} /$ per millimole of total purines (Vagnoni and Broderick, 1997), microbial protein was estimated to be 1183,1383 , and $1503 \mathrm{~g}$ of $\mathrm{CP} /$ per day. Assuming 64\% metabolizability (NRC, 2001), 128 and $205 \mathrm{~g} / \mathrm{d}$ more metabolizable protein from microbial synthesis was computed when dietary fiber was reduced from $36 \% \mathrm{NDF}$ to 32 and $28 \%$ NDF. These estimates were at disparity from the much lower average of $65 \mathrm{~g} /$ $\mathrm{d}$ more metabolizable protein from ruminal microbes computed earlier based on NRC (2001) assumptions, which suggested that microbial protein may have been more important than increased RUP supply in improving protein status in the present trial.

\section{Milk Nitrogen Fractions}

When dietary CP increased, there were stepwise increases in MUN and milk NPN concentrations and in the proportion of MUN in milk NPN; these were highly significant linear trends (Table 2). A significant quadratic effect of dietary CP on milk allantoin also was detected; a minimum was predicted at $17.0 \%$ CP. Sig- nificant linear increases in milk allantoin and linear reductions in MUN and proportion of MUN in milk NPN were observed with increasing dietary energy content (Table 3). In earlier work, allantoin accounted for about $90 \%$ of the total purine derivatives excreted in cow urine (Vagnoni et al., 1997; Valadares et al., 1999) that originate largely from microbial purines from the rumen. There is evidence that milk allantoin may reflect plasma allantoin and thus may be related to urinary allantoin excretion (Giesecke et al., 1994; Stangassinger et al., 1995). Analyzing data from 10 feeding studies with lactating cows, Timmermans et al. (2000) reported that milk allantoin concentrations were correlated $\left(\mathrm{r}^{2}=0.28\right)$ to duodenal flows of microbial N. Although there were quadratic effects of dietary CP (Table 2 ) and linear effects of dietary NDF (Table 3) on milk allantoin, the changes observed over the ranges fed in the present trial here were small: reducing dietary NDF from 36 to $28 \%$ increased estimated urinary excretion of purine derivatives $19 \%$, but milk allantoin increased by only $3 \%$. Moreover, despite trends for linear relationships with dietary NDF $(P=0.07)$ and NFC $(P=0.07)$, milk allantoin concentration was unrelated to estimated urinary excretion of allantoin $(P=0.67)$ and total purine derivatives $(P=0.55)$. Milk allantoin was measured by an HPLC assay (Shingfield and Offer, 1998a) in this trial and ranged from 0.082 to 0.336 $\mathrm{m} M$. Half of the milk samples also were analyzed for allantoin using a more common and convenient assay based on alkaline then acidic hydrolysis of allantoin to glyoxylate, followed by glyoxylate detection by reaction with phenylhydrazine and an oxidizing agent (Vogels 
and van der Grift, 1970). Average allantoin concentration using the phenylhydrazine method was $1.14 \mathrm{~m} M$, vs. $0.142 \mathrm{mM}(13 \%)$ by HPLC, and the results of the two assays were not correlated $(P=0.55)$. Earlier, we found mean milk allantoin of about $1.0 \mathrm{mM}$ (Vagnoni and Broderick, 1997) and $0.6 \mathrm{~m} M$ (Valadares et al., 1999) using phenylhydrazine-based assays. Although the contribution from glyoxylate already present in milk can be removed (Vogels and van der Grift, 1970), other compounds may interfere with this assay, including uric acid that will be partially hydrolyzed to glyoxylate (Vogels and van der Grift, 1970). Uric acid can be synthesized within the mammary gland, and milk uric acid was found to be poorly related to urinary excretion of uric acid or total purine derivatives (Stangassinger et al., 1995). Earlier German work showing positive correlations of urinary purine derivatives to milk allantoin reported mean allantoin concentration of $0.20 \mathrm{mM}$ determined by HPLC (Giesecke et al., 1994). However, Shingfield and Offer (1998c) detected no effect of dietary energy content on milk allantoin assayed using an HPLC technique.

It is well known that MUN levels are sensitive to dietary CP content (e.g., Broderick and Clayton, 1997). Jonker et al. (1998) developed a simple model using MUN to predict CP intake and $\mathrm{N}$ excretion. This group recently modified the model's coefficients to reflect updated infrared calibrations that have lowered apparent MUN concentrations in commercial practice (Kohn et al., 2002). In the present trial, a disparity was apparent between MUN levels determined by infrared scanning and the colorimetric assay used in all of our trials. Therefore, MUN was reanalyzed using a third assay based on urease hydrolysis. Results obtained using urease did not agree precisely with those from the other two methods, but colorimetric data were more similar. Simple regression of infrared MUN data on urease MUN yielded an $\mathrm{r}^{2}$ of only 0.20 (Figure 1a), whereas the $\mathrm{r}^{2}$ from the comparable regression with colorimetric MUN data was 0.72 (Figure 1b). Infrared MUN results resolved into different relationships for each of the eight sets of milk samples analyzed over the course of the trial (Figure 1a). The MUN values within each set were more closely related to urease MUN: simple $\mathrm{r}^{2}$ ranged from 0.45 to 0.89 for the eight sets but there were large differences among slopes (range $=0.88$ to 1.55 ) and intercepts (range $=-3.25$ to +3.38 ) of these eight regressions. Weekly recalibration of the infrared MUN assay may have contributed to this source of variation. A smaller run effect also was noted with the colorimetric MUN determinations. Although these samples were held to the end of the trial, they were assayed in three separate groups, the results of which yielded regressions on urease MUN with $\mathrm{r}^{2}$ ranging from 0.66 to 0.83 .

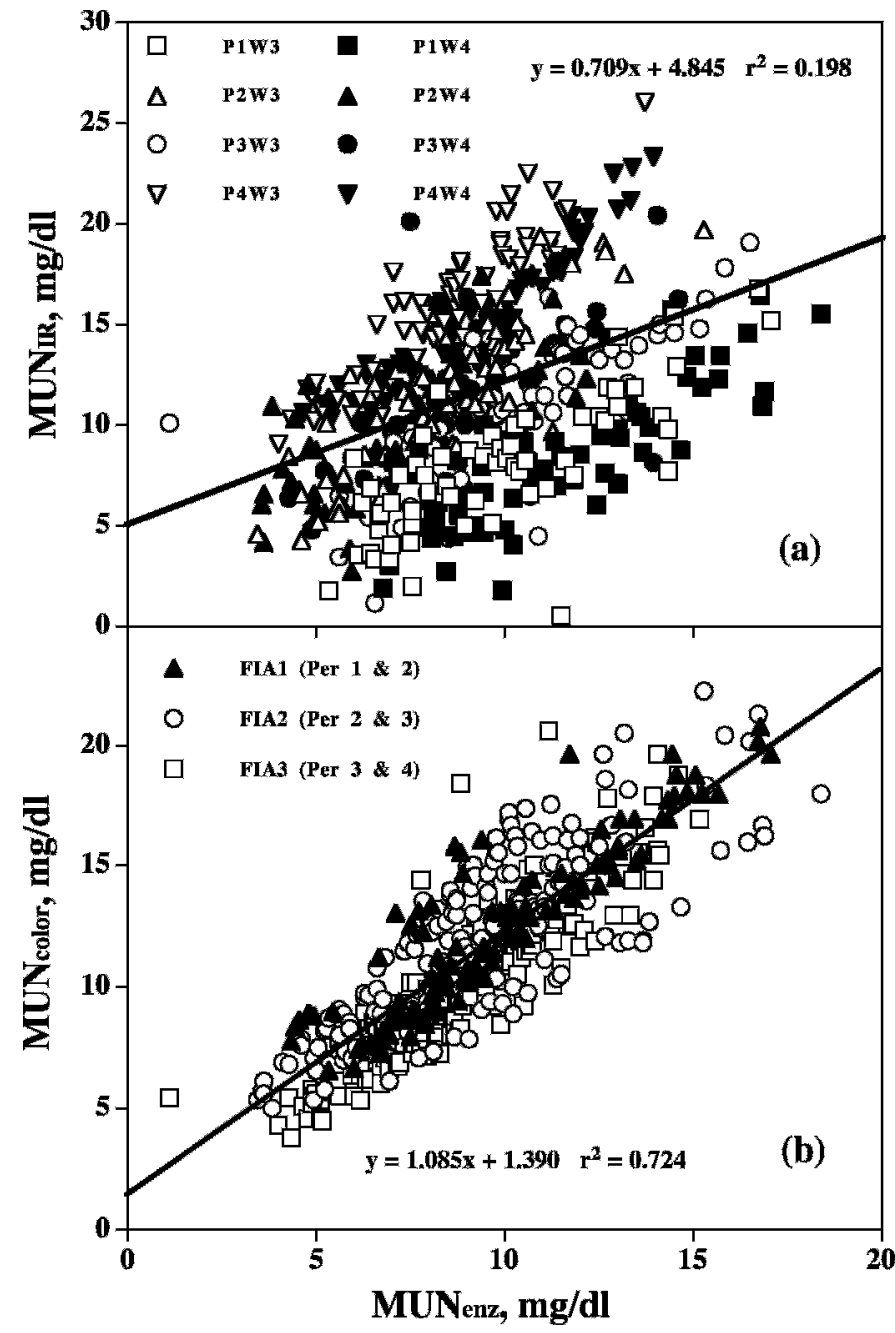

Figure 1. Comparison of milk urea N (MUN) determined using a urease enzymatic procedure (MUNenz) with MUN values assayed by infrared (MUN $\mathrm{IR}_{\mathrm{IR}}$; a) or colorimetric (MUNcolor; b) methods. Infrared MUN determinations were conducted at the time of each of the eight milk samplings, from period 1, wk 3 (P1W3) through period 4, wk 4 (P4W4). Colorimetric MUN determinations were conducted on the flow-injection analyzer (FIA) in three separate groups of 160 to 180 samples each: samples in group 1 (FIA1) were from periods 1 and 2; samples in group 2 (FIA2) were from periods 2 and 3 ; and samples in group 3 (FIA3) were from periods 3 and 4 . Equations were from simple regression of all MUN observations made by infrared or colorimetric assay on MUN values determined using urease assay.

There was also less variation among the slopes (range $=0.97$ to 1.19 ) and intercepts (range $=-0.29$ to 1.75 ) of these regressions.

Generally, there were strong linear relationships between urinary $\mathrm{N}$ excretion, intake of $\mathrm{CP}$ and energy, and MUN determined by the colorimetric method (Table 6). Most sources of feed CP have high true digestibilities (NRC, 2001); therefore, increased dietary CP intake that does not result in deposited or secreted $\mathrm{N}$ 
Table 6. Significant linear and quadratic regressions on milk urea N and intake of CP and NFC. ${ }^{1}$

\begin{tabular}{|c|c|c|c|c|}
\hline Variable (Y) & & Equation & $\mathrm{R}^{2}$ & Maximum $^{2}$ \\
\hline \multicolumn{5}{|c|}{ Urinary excretion $(\mathrm{MUN}, \mathrm{mg} / \mathrm{dl})^{3}$} \\
\hline Urea $N, g / d$ & Linear & $\mathrm{Y}=88.8+11.6 \mathrm{MUN}$ & 0.731 & - \\
\hline Total N, g/d & Linear & $\mathrm{Y}=111.6+11.2 \mathrm{MUN}$ & 0.728 & - \\
\hline $\mathrm{CP}, \%$ of DM & Quadratic & $\mathrm{Y}=12.0+0.508 \mathrm{MUN}-0.00926 \mathrm{MUN}^{2}$ & 0.798 & $27.4 \mathrm{mg} / \mathrm{dl}$ \\
\hline CP intake, $\mathrm{kg} / \mathrm{d}$ & Linear & $\mathrm{Y}=2.44+0.100 \mathrm{MUN}$ & 0.846 & - \\
\hline $\mathrm{NDF}, \%$ of DM & Linear & $\mathrm{Y}=46.5-0.408 \mathrm{MUN}$ & 0.403 & - \\
\hline NDF intake, $\mathrm{kg} / \mathrm{d}$ & Linear & $\mathrm{Y}=8.97+0.0101 \mathrm{MUN}$ & 0.698 & - \\
\hline \multicolumn{5}{|c|}{ Milk and protein yield $(\mathrm{CPI}, \mathrm{kg} / \mathrm{d})^{4}$} \\
\hline Milk, $\mathrm{kg} / \mathrm{d}$ & Linear & $\mathrm{Y}=21.6+1.99 \mathrm{CPI}$ & 0.862 & - \\
\hline Protein, kg/d & Linear & $\mathrm{Y}=0.669+0.0559 \mathrm{CPI}$ & 0.734 & - \\
\hline True protein, kg/d & Linear & $\mathrm{Y}=0.676+0.0389 \mathrm{CPI}$ & 0.721 & - \\
\hline \multicolumn{5}{|c|}{ Milk and protein yield (NFCI, $\mathrm{kg} / \mathrm{d})^{4}$} \\
\hline Milk, $\mathrm{kg} / \mathrm{d}$ & Linear & $\mathrm{Y}=7.40+2.33 \mathrm{NFCI}$ & 0.926 & - \\
\hline Protein, kg/d & Linear & $\mathrm{Y}=0.157+0.0782 \mathrm{NFCI}$ & 0.851 & - \\
\hline
\end{tabular}

will be catabolized largely to urea. Blood urea readily equilibrates with milk (Gustafsson and Palmquist, 1993); hence, it was expected that MUN would be a reliable predictor of urinary $\mathrm{N}$ excretion. Although curvilinearity was not anticipated, the quadratic term for the relationship of MUN with dietary CP content was significant $(P=0.002)$; however, the improvement in fit was small (linear $\mathrm{r}^{2}=0.787$ vs. quadratic $\mathrm{r}^{2}=0.798$ ). Dietary energy density, as indicated negatively by NDF and positively by NFC, was less accurately predicted by MUN than dietary CP. Intakes of NDF and NFC were similarly explained by MUN concentration $\left(\mathrm{r}^{2}=\right.$ 0.70). Milk urea may prove useful for rapidly identifying sudden alterations in dietary CP content or intakefor example, as may occur with a change in source of legume silage. This could aid in closer control of dietary $\mathrm{CP}$ content and help reduce overfeeding of $\mathrm{CP}$ and excessive excretion of the environmentally labile urinary $\mathrm{N}$ accompanying CP overfeeding (James et al., 1999; Rotz et al., 1999). Regressing dietary content and intake of $\mathrm{CP}, \mathrm{NFC}$, and NDF on MUN data determined using infrared and urease assays yielded equations with different slopes and intercepts, but correlation coefficients of very nearly the same magnitude as those for colorimetric MUN in Table $6\left(\mathrm{r}^{2}=0.27\right.$ to 0.84 for infrared MUN and $\mathrm{r}^{2}=0.27$ to 0.86 for urease MUN). Of course, differing numeric relationships among nutrient intake data and MUN values generated by the different assays showed the importance of establishing a standardized MUN assay that could to be used to adjust diets to help minimize $\mathrm{N}$ losses to the environment from commercial dairies.
There were linear correlations between milk and protein yields and intake of both CP and NFC (Table 6); these relationships were stronger for NFC than CP. The slopes from regressions relating NFC intake to yield accounted for somewhat more of the predicted affect than did those relating CP intake to yield: at the overall mean NFC intake $(9.1 \mathrm{~kg} / \mathrm{d}), 74$ to $82 \%$ of the response was accounted for by slope vs. only 17 to $25 \%$ of the response due to slope at the overall mean CP intake $(3.7 \mathrm{~kg} / \mathrm{d})$. British workers also recently found that milk and protein yields in cows fed grass silagebased diets were increased much more by starch supplementation (Kebreab et al., 2000), particularly corn starch (Castillo et al., 2001b), than by protein supplementation (Castillo et al., 2001a). As discussed earlier, increasing dietary energy content improves milk production by increasing protein supply through stimulating microbial protein formation and by increasing energy supply to the animal. Decreasing dietary forage gave rise to linear increases in both milk and protein yields over the range from 25 to $43 \%$ NFC (Valadares et al., 2000). Grinding of high-moisture corn to enhance ruminal fermentation and microbial growth has been shown to improve both milk and protein yield (Ekinci and Broderick, 1997; Wilkerson et al., 1997). So long as RDP supply is adequate, milk and protein yield will continue to respond to increased energy intake until production is suppressed by the adverse ruminal effects of excessive concentrate intake (Oliveira et al., 1993).

\section{SUMMARY AND CONCLUSIONS}

Diets containing three levels of protein, each at three levels of energy, were fed to lactating cows. Adding 
SBM to increase CP from 15.1 to 16.7 and $18.4 \%$ had only small positive effects on DMI and milk and protein yield; also, FCM and milk fat yield was higher at 16.7 and $18.4 \% \mathrm{CP}$ than at $15.1 \% \mathrm{CP}$. However, there were large increases in milk urea and NPN and in urinary $\mathrm{N}$ excretion and a substantial decrease in $\mathrm{N}$ efficiency over this range of dietary CP. Increasing dietary energy by reducing forage (from 36 to $28 \% \mathrm{NDF}$ ) gave rise to linear increases in BW gain, yield of milk and milk components (except for fat), and milk/DMI and milk N/ $\mathrm{N}$ intake, as well as linear decreases in milk urea and urinary $\mathrm{N}$ excretion. Increasing dietary energy resulted in comparable increases in milk $\mathrm{N}$ secretion and decreases in excretion of urinary N. Results of this trial indicated that, regardless of dietary energy content, feeding $16.7 \% \mathrm{CP}$ was adequate for supporting milk production. Reducing dietary $\mathrm{CP}$ to the requirement will be effective for reducing excessive excretion of the most environmentally labile form of $\mathrm{N}$.

\section{ACKNOWLEDGMENTS}

The authors thank the farm crew for harvesting and storing the forages and Len Strozinski and the barn crew for animal care and assistance in sampling at the US Dairy Forage Center Research Farm (Prairie du Sac, WI), Wendy Radloff and Mary Becker for assisting with laboratory analyses, and Murray Clayton and Peter Crump for assisting with statistical analyses.

\section{REFERENCES}

Association of Official Analytical Chemists. 1980. Official Methods of Analysis. 13th ed. AOAC, Washington, DC.

Bal, M. A., R. D. Shaver, A. G. Jirovec, K. J. Shinners, and J. G. Coors. 2000. Crop processing and chop length of corn silage: Effects on intake, digestion, and milk production by dairy cows. J. Dairy Sci. 83:1264-1273.

Broderick, G. A. 1986. Relative value of solvent and expeller soybean meal for lactating dairy cows. J. Dairy Sci. 69:2948-2958.

Broderick, G. A., and M. K. Clayton. 1997. A statistical evaluation of animal and nutritional factors influencing concentrations of milk urea nitrogen. J. Dairy Sci. 80:2964-2971.

Broderick, G. A., R. G. Koegel, M. J. C. Mauries, E. Schneeberger, and T. J. Kraus. 1999. Effect of feeding macerated alfalfa silage on nutrient digestibility and milk yield in lactating dairy cows. J. Dairy Sci. 82:2472-2485.

Broderick, G. A., R. P. Walgenbach, and S. Maignan. 2001. Production of lactating dairy cows fed alfalfa or red clover silage at equal dry matter or crude protein contents in the diet. J. Dairy Sci. 84:1728-1737.

Cadorniga, C. P., and L. D. Satter. 1993. Protein versus energy supplementation of high alfalfa silage diets for early lactation cows. J. Dairy Sci. 76:1972-1980.

Castillo, A. R., E. Kebreab, D. E. Beever, J. H. Barbi, J. D. Sutton, H. C. Kirby, and J. France. 2001a. The effect of protein supplementation on nitrogen utilization in lactating dairy cows fed grass silage diets. J. Anim. Sci. 79:240-246.

Castillo, A. R., E. Kebreab, D. E. Beever, J. H. Barbi, J. D. Sutton, H. C. Kirby, and J. France. 2001b. The effect of energy supplementation on nitrogen utilization in lactating dairy cows fed grass silage diets. J. Anim. Sci. 79:247-253.
Cochran, R. C., D. C. Adams, J. D. Wallace, and M. L. Galyean. 1986. Predicting digestibility of different diets with internal markers: Evaluation of four potential markers. J. Anim. Sci. 63:1476-1487.

Ekinci, C., and G. A. Broderick. 1997. Effect of processing high moisture ear corn on ruminal fermentation and milk yield. J. Dairy Sci. 80:3298-3307.

Faldet, M. A., and L. D. Satter. 1991. Feeding heat-treated full fat soybeans to cows in early lactation. J. Dairy Sci. 74:3047-3054.

Gustafsson, A. H., and D. L. Palmquist. 1993. Diurnal variation of rumen ammonia, serum urea, and milk urea in dairy cows at high and low yields. J. Dairy Sci. 76:475-484.

Giesecke, D., L. Ehrentreich, M. Stangassinger, and F. Ahrens. 1994. Mammary and renal excretion of purine metabolites in relation to energy intake and milk yield in dairy cows. J. Dairy Sci. 77:2376-2381.

Hintz, R. W., D. R. Mertens, and K. A. Albrecht. 1995. Effects of sodium sulfite on recovery and composition of detergent fiber and lignin. J. AOAC. 78:16-22.

Hristov, A., and G. A. Broderick. 1996. Synthesis of microbial protein in ruminally cannulated cows fed alfalfa silage, alfalfa hay or corn silage. J. Dairy Sci. 79:1627-1637.

Huhtanen, P., K. Kaustell, and S. Jaakkola. 1994. The use of internal markers to predict total digestibility and duodenal flow of nutrients in cattle given six different diets. Anim. Feed Sci. Technol. 48:211-227.

James, T., D. Meyer, E. Esparza, E. J. Depeters, and H. Perez-Monti. 1999. Effects of dietary nitrogen manipulation on ammonia volatilization from manure from Holstein heifers. J. Dairy Sci. 82:2430-2439.

Jonker, J. S., R. A. Kohn, and R. A. Erdman. 1998. Using milk urea nitrogen to predict nitrogen excretion and utilization efficiency in lactating dairy cattle. J. Dairy Sci. 81:2681-2692.

Kebreab, E., A. R. Castillo, D. E. Beever, D. J. Humphries, and J. France. 2000. Effects of management practices prior to and during ensiling and concentrate type on nitrogen utilization in dairy cows. J. Dairy Sci. 83:1274-1285.

Kohn, R. A., K. F. Kalscheur, and E. Russek-Cohen. 2002. Evaluation of models to estimate urinary nitrogen and expected milk urea nitrogen. J. Dairy Sci. 85:227-233.

Littell, R. C., G. A. Milliken, W. W. Stroup, and R. D. Wolfinger. 1996. SAS System for Mixed Models. SAS Inst., Inc., Cary, NC.

Mathis, C. P., R. C. Cochran, G. L. Stokka, J. S. Heldt, B. C. Woods, and K. C. Olson. 1999. Impacts of increasing amounts of supplemental soybean meal on intake and digestion by beef steers and performance by beef cows consuming low-quality tallgrass-prairie forage. J. Anim. Sci. 77:3156-3162.

Misra, A. K., and S. S. Thakur. 2001. Effect of dietary supplementation of sodium salt of isobutyric acid on ruminal fermentation and nutrient utilization in a wheat straw based low protein diet fed to crossbred cattle. Asian-Australasian J. Anim. Sci. 14:479-484

Muck, R. E. 1982. Urease activity in bovine feces. J. Dairy Sci. 65:2157-2163.

Muck, R. E. 1987. Dry matter level effects on alfalfa silage quality. 1. Nitrogen transformations. Trans. ASAE 30:7-14.

Nagel, S. A., and G. A. Broderick. 1992. Effect of formic acid or formaldehyde treatment of alfalfa silage on nutrient utilization by dairy cows. J. Dairy Sci. 75:140-154.

National Research Council. 2001. Nutrient Requirements of Dairy Cattle. 7th rev. ed. Natl. Acad. Sci., Washington, DC.

Oliveira, J. S., J. T. Huber, D. Ben-Ghedalia, R. S. Swingle, C. B. Theurer, and M. Pessarakali. 1993. Influence of sorghum grain processing on performance of lactating dairy cows. J. Dairy Sci. 76:575-581.

Oser, B. L. 1965. Hawk's Physiological Chemistry. 14th ed. McGrawHill, New York, NY.

Rinne, M., S. Jaakkola, K. Kaustell, T. Heikkila, and P. Huhtanen. 1999. Silages harvested at different stages of grass growth vs. concentrate foods as energy and protein sources in milk production. Anim. Sci. 69:251-263. 
Rotz, C. A., L. D. Satter, D. R. Mertens, and D. E. Muck. 1999. Feeding strategy, nitrogen cycling, and profitability of dairy farms. J. Dairy Sci. 82:2841-2855.

SAS User's Guide: Statistics, Version 6 Edition. 1989. SAS Inst., Inc., Cary, NC.

Shahani, K. M., and H. H. Sommer. 1951. The protein and nonprotein nitrogen fractions in milk. I. Methods of analysis. J. Dairy Sci. 34:1003-1009.

Shingfield, K. J., and N. W. Offer. 1998a. Determination of allantoin in bovine milk by high-performance liquid chromatography. J. Chromatogr. B 706:342-346.

Shingfield, K. J., and N. W. Offer. 1998b. Evaluation of the spot urine sampling technique to assess urinary purine derivative excretion in lactating dairy cows. Anim. Sci. 66:557-568.

Shingfield, K. J., and N. W. Offer. 1998c. Evaluation of milk allantoin excretion as an index of microbial protein supply in lactating dairy cows. Anim. Sci. 67:371-385.

Sklan, D., R. Ashkenazi, A. Braun, A. Devorn, and K. Tabori. 1992. Fatty acids, calcium soaps of fatty acids, and cottonseeds fed to high yielding cows. J. Dairy Sci. 75:2463-2472.

Stangassinger, M., X. B. Chen, J. E. Lindberg, and D. Giesecke. 1995. Metabolism of purines in relation to microbial production. Pages 387-406 in Ruminant Physiology: Digestion, Metabolism, Growth and Reproduction. W. V. Engelhardt, S. Leonhard-Marek, G. Breves, and D. Giesecke, ed. Ferdinand Enke Verlag, Stuttgart, Germany.

Timmermans, S. J., Jr., L. M. Johnson, J. H. Harrison, and D. Davidson. 2000. Estimation of the flow of microbial nitrogen to the duodenum using milk uric acid or allantoin. J. Dairy Sci. 83:1286-1299.
Valadares, R. F. D., G. A. Broderick, S. C. Valadares Filho, and M. K. Clayton. 1999. Effect of replacing alfalfa silage with high moisture corn on ruminal protein synthesis estimated from excretion of total purine derivatives. J. Dairy Sci. 82:2686-2696.

Valadares Filho, S. C., G. A. Broderick, R. F. D. Valadares, and M. K. Clayton. 2000. Effect of replacing alfalfa silage with high moisture corn on nutrient utilization and milk production. J. Dairy Sci. 83:106-114.

Vagnoni, D. B., and G. A. Broderick. 1997. Effects of supplementation of energy or ruminally undegraded protein to lactating cows fed alfalfa hay or silage. J. Dairy Sci. 80:1703-1712.

Vagnoni, D. B., and G. A. Broderick, M. K. Clayton, and R. D. Hatfield. 1997. Excretion of purine derivatives by Holstein cows abomasally infused with incremental amounts of purines. J. Dairy Sci. 80:1695-1702.

Van Soest, P. J., J. B. Robertson, and B. A. Lewis. 1991. Methods for dietary fiber, neutral detergent fiber and nonstarch polysaccharides in relation to animal nutrition. J. Dairy Sci. 74:35833597.

Varel, V. H., J. A. Nienaber, and H. C. Freetly. 1999. Conservation of nitrogen in cattle feedlot waste with urease inhibitors. J. Anim. Sci. 77:1162-1168.

Vogels, G. D., and C. van der Grift. 1970. Differential analyses of glyoxylate derivatives. Anal. Biochem. 33:143-157.

Weimer, P. J. 1992. Cellulose degradation by ruminal microorganisms. Crit. Rev. Biotechnol. 12:189-223.

Wilkerson, V. A., B. P. Glenn, and K. R. McLeod. 1997. Energy and nitrogen balance in lactating cows fed diets containing dry or high moisture corn in either rolled or ground form. J. Dairy Sci. 80:2487-2496. 